\title{
Relative Autonomy Revisited: Reply to Francesca Merlan
}

\author{
Frances Morphy and Howard Morphy
}

$\mathrm{F}$ rancesca Merlan's response (this issue) to our article ("Anthropological Theory and Government Policy in Australia's Northern Territory: The Hegemony of the "Mainstream'" [AA 115(2):174-187]) draws attention to complex issues of social theory that lie at the heart of anthropological and sociological discourse. Anthropology, through the use of concepts such as cultural relativism, cultural translation, value-creation processes, and systems of social organization, acknowledges a world in which human groups, however defined, have experienced different historical trajectories and are differentiated from one another in significant ways. Those differences are often important factors underlying individual and group identity formation and reproduction. They may be constituted in different legal and institutional structures that frame people's lives and their possibilities for action and reflect differing value-creation processes that influence attitudes to self and other. Change is a constant: these factors are variable, the groups or entities that are identified are subject to change over time, boundaries are fuzzy, values change, new institutional structures develop. The majority of anthropologists who write about "culture" and "society" acknowledge the abstract, theoreti$\mathrm{cal}$, and contingent nature of such concepts and acknowledge that they are using them as components of an overall theoretical framework that exists in a dialogic relationship with the data that they record and analyze. It is almost too easy to criticize people who use the concepts of "culture" and "society" by implying that they have rigid bounded entities in mind rather than more abstract concepts that can be applied to interpret real-world situations. The durability of regional sociocultural systems is an important issue for anthropologists to engage with, in particular in the context of change, colonialism, and state formation.

Merlan writes that we "treat the intercultural as if interrelation were limited to particular contact zones or spaces" (this issue). In our June 2013 American Anthropologist article, we tried to be very clear in acknowledging the complexity of Merlan's position and pointing out that she does "not argue for any simplistic dualism" (p.177) and that the intercultural is in many respects a conceptual, not simply a physical, space.
Her misreading of our argument enables her to suggest that we view "cultures as different entities, with only limited contact zones between them" (this issue). The first part of this statement is true to an extent, without the implied reification, in that we do think it is important to take relevant cultural differences into account in anthropological analyses of contemporary contexts. But the second part is not.

Much of our work has been focused on the interaction between Yolngu and non-Yolngu society, and on the resulting changes that have occurred in different aspects of Yolngu society over time. In our June 2013 American Anthropologist article, we summarized and cited a detailed analysis of change over time in Yolngu mortuary rituals from the pre-mission era to the present (see also Morphy and Morphy 2011).

Frances Morphy's work has addressed interactions between Yolngu and non-Yolngu in the context of a legal case, the governance of an indigenous organization, and regional population studies (F. Morphy 2012). ${ }^{1}$ She completed a multisited ethnography of the Indigenous Enumeration Strategy as it operated in the 2006 national census, following the process from the local level (the initial filling in of the forms) to the national level (the processing of the data and its final transformation into statistical information; see F. Morphy 2007). Her research reveals the resilience of local forms of organization from the household to the regional level and the patterns of mobility that result, and it simultaneously analyzes the ways in which difference from mainstream "norms" is masked by the census process. The asymmetrical relationship that Merlan refers to between town workers and indigenous Australians such as Julie is thus shown to be a factor that also operates at the level of the state, which imposes its own categories and renders local categories invisible.

Relationality is an important component of understanding social processes, but it is also necessary to analyze what differences are brought to the relationship. To focus on that difference is not mystification but, rather, clarification of the terms of the relationship; the very term intercultural implies relationality between two or more "entities," and it is surely more mystifying to regard one of those entities as more or less entirely produced by the other. Such a schema 
reduces contemporary Aboriginal sociocultural systems and the regimes of value that underpin them to the status of images captured in two opposed mirrors - receding into eternity, intriguing, but not real. Our schema focuses on the properties of the object not the image.

Howard Morphy's writing on Yolngu art has always been set in the context of interaction with the wider Australian society and the impact of the global art market on the local scene. In Becoming Art (H. Morphy 2008), he provides a detailed analysis of the ways in which Yolngu art has been a site of interaction with outsiders from pre-European colonial times to the present. He argues that understanding the historical process whereby Yolngu art has both gained widespread recognition outside the context of Yolngu society and maintained its value internally requires the development of a cross-cultural concept of art. If art is redefined as a particular way of acting in the world, Western fine art is just one manifestation of this process rather than being the paradigmatic category. Morphy shows that Yolngu recognize the synergistic relationships between art as they use it in internal contexts and as they use it in their relationship with outsiders. This does not make the work that they produce "intercultural" any more than any other art produced for exhibition in contemporary gallery contexts is intercultural, unless the definition of intercultural becomes so broad as to be meaningless or the term is relevant to the intentionality of the particular artist. We are not clear what Merlan means by saying that Aboriginal art appears "'traditional' in cultural content" (this issue), and this is not terminology we would employ. Yolngu art is likely never to have been "sealed off" from outsiders, and its recent trajectory incorporates several generations of interaction with Macassan traders in the centuries before European colonization. Our argument is not that Yolngu society has been uninfluenced by outsiders or that there are domains within their society that can be considered in isolation from the broader context of their interaction with wider Australian society. Howard Morphy's research on art shows clearly how changes in the use and contexts of art consequent on relationships with outsiders have also provided contexts for change within Yolngu societyfor example, in gender relations and regional governance. In no sense does the concept of relative autonomy "quarantine" change nor do we consider that autonomy in action implies separation.

We certainly do not argue that government policy has been directly informed by the intercultural. Rather, we advance the argument that the intercultural is not the best framework for understanding the historical process of the incorporation of Aboriginal Australians within the state. We have argued that a theoretical perspective that takes account of the differences that exist in particular regions between indigenous Australians and the "mainstream" society, and the motivations of indigenous Australians associated with particular value-creation processes, need to be taken into account in order to understand present trajectories and in- form government policy. We argue only that there is an unfortunate synergy between the intercultural and recent policy settings, in that both downplay the significance of the agency of indigenous people acting in accordance with their own systems of value. We acknowledge that whether or not indigenous people in Katherine will continue to "think and act in terms of rainbow serpents in town spaces" (this issue) is an empirical question. Our concern in our $A A$ article was not to hypothesize how such beliefs may change over time but, rather, to examine the consequences of people's thoughts and actions in the present for their interaction with others and to develop models that reflect these dynamics. In this project, our position cannot be read as some naïve acceptance that the Yolngu view is privileged and that no further analysis is possible. It is the Yolngu, not we, who articulate the "two worlds" view, and this may indeed elide or obscure the true nature of their relations with the state. It is the Yolngu, not we, who characterize their position as "encapsulated" but not "colonized." But their view is their view, and it reflects their sense of their relatively autonomous way of being, which in turn frames, in powerful ways, their actions and their sense of themselves in their relationships with the non-Yolngu world.

The research we have undertaken and the concept of relative autonomy that we highlighted in our $A A$ article are directly relevant to the issues of disadvantage that Merlan raises. We have argued that the failure to take into account the present motivations and value orientations of Yolngu people has created a disjunction between government policies and their desired outcomes.

Frances Morphy Centre for Aboriginal Economic Policy Research, Australian National University, Canberra, ACT 0200 Australia; frances.morphy@anu.edu.au

Howard Morphy Research School of Humanities and the Arts, Australian National University, Canberra, ACT 0200, Australia; howard.morphy@anu.edu.au

\section{NOTE}

1. Several other relevant publications were referenced in our original article and are not re-referenced here.

\section{REFERENCES CITED}

Morphy, Frances

2007 The Transformation of Input into Output: At the Melbourne Data Processing Centre. In Agency, Contingency and Census Process: Observations of the 2006 Indigenous Enumeration Strategy in Remote Aboriginal Australia. CAEPR Monograph No. 28. Frances Morphy, ed. Pp. 101-112. Canberra: Australian National University ePress.

2012 The Yolngu in Place: Designing a Population Survey for North East Arnhem Land. Agreements, Treaties and 
Negotiated Settlements Project Working Paper No. 3. Melbourne: ATNS Project, University of Melbourne.

Morphy, Frances, and Howard Morphy

2011 "Soon We Will Be Spending All Our Time at Funerals": Yolngu Mortuary Rituals in an Epoch of Constant Change. In Returns to the Field: Multitemporal Research and Contemporary Anthropology. Signe Howe and Aud Talle, eds. Pp. 49-72. Bloomington: Indiana University Press.

Morphy, Howard

2008 Becoming Art: Exploring Cross-Cultural Categories. Sydney: University of New South Wales Press. 